\title{
List of Abbreviations and Bibliography
}

\section{Abbreviations}

Grammatical Abbreviations

det. Determinate

f. Feminine

f.s. Feminine singular

hypoc. Hypocoristic

m. Masculine

m.p. Masculine plural

m.s. Masculine singular

p. Plural

s. Singular

Since reference is made to both Aram. and Arab names, I choose the neutral paradigm $C C C$ instead of $q t \underline{l}$ and $f^{\prime} l$.

Languages and Scripts

Akk. Akkadian

Amm. Ammonite

ANA Ancient North-Arabian

Aram. Aramaic

ASA Ancient South-Arabian

Bab. Babylonian

Dad. Dadanitic

EA Egyptian Aramaic

Hadr. Hadramitic

Hebr. Hebrew

Hism. Hismaic

Iran. Iranian

JBA Jewish Babylonian Aramaic

LB Late-Babylonian

MA Middle Aramaic

Min. Minaic

MP Middle Persian
MSA Modern Standard Arabic

NA Neo-Assyrian

Nab. Nabataean

NB Neo-Babylonian

NWS North-Western Semitic

OA Old Aramaic

OffA Official Aramaic

Palm. Palmyrene

Phoen. Phoenician

Qat. Qatabanic

Sab. Sabaic

Saf. Safaitic

Syr. Syriac

Tham. Thamudic

Ug. Ugaritic

Transliteration Conventions

[x] missing letter(s)

' $\mathrm{x}$ ' partially damaged letter(s)

$<\mathrm{x}>$ integration

$\{\mathrm{x}\}$ deletion

Other Abbreviations

Obv Obverse

Rev Reverse

r.e. Right edge

le.e. Left edge

u.e. Upper edge

lo.e. Lower edge 


\section{Bibliographical abbreviations}

AHw $=$ Von Soden, Wolfram (196581). Akkadisches Handwörterbuch. Wiesbaden: Otto Harrassowitz.

CAD = Biggs, Robert D. et al. (eds.) (1964-2010). The Assyrian Dictionary of the Oriental Institute of the University of Chicago. 21 vols. Chicago: The Oriental Institute.

CIS $=$ Académie des inscriptions et belles lettres (1881-1962). Corpus Inscriptionum Semiticarum. Parisiis: E Reipublicae Typographeo. CSD = Payne Smith, Robert (1903). A Compendious Syriac Dictionary; Founded upon the Thesaurus Syriacus. Oxford: Clarendon Press.

DNWSI = Hoftijzer, Jacob; Jongeling, Karel (eds.) (1995). Dictionary of the North-West Semitic Inscriptions. Leiden; New YorkKöln: E.J. Brill.

DUL = del Olmo Lete, Gregorio; Sanmartín, Joaqín (2015). A Dictionary of the Ugaritic Language in the Alphabetic Tradition. 3rd revised ed. Translated and edited by Wilfred G.E. Watson. Leif den; Boston: Brill. Handbuch der Orientalistik 112.

HALOT = Koehler, Ludwig; Baumgartner, Walter (1994-2000). The Hebrew and Aramaic Lexicon of the Old Testament. 3rd ed. Subsequently revised by Walter Baumgartner and Johann J. Stamm. Translated and edited under the supervision of Mervyn E.J. Richardson. Leiden: Brill.

HIn. = Harding, Gerald L. (1971). An Index and Concordance of Pre-Islamic Arabian Names and
Inscriptions. Toronto: University of Toronto Press. Near and Middle East Series 8.

Lane = Lane, Edward W. (1863-93). An Arabic-English Lexicon. London; Edinburgh: Williams and Norgate.

OSI = Drijvers, Han J.W.; Healey, John F. (1999). The Old Syriac Inscriptions of Edessa and Osrhoene. Texts, Translations and Commentary. Leiden; Boston; Köln: Brill. Handbuch der Orientalistik 42.

PAT $=$ Hillers, Delbert R.; Cussini, Eleonora (1996). Palmyrene Aramaic Texts. Baltimore; London: The Johns Hopkins University Press. Publications of the Comprehensive Aramaic Lexicon Project III.

PNA $1 / \mathrm{I}=$ Radner, Karen (ed.) (1998). The Prosopography of the Neo-Assyrian Empire 1/I: A. Helsinki: The Neo-Assyrian Text Corpus Project.

PNA 1/II = Radner, Karen (ed.) (1999). The Prosopography of the Neo-Assyrian Empire 1/II: B-G. Helsinki: The Neo-Assyrian Text Corpus Project.

PNA 2/I = Baker, Heather D. (ed.) (2000). The Prosopography of the Neo-Assyrian Empire 2/I: $H-K$. Helsinki: The Neo-Assyrian Text Corpus Project.

PNA 2/II = Baker, Heather D. (ed.) (2001). The Prosopography of the Neo-Assyrian Empire 2/II: L-N. Helsinki: The Neo-Assyrian Text Corpus Project. 
PNA $3 / \mathrm{I}=$ Baker, Heather D. (ed.) (2002). The Prosopography of the Neo-Assyrian Empire 3/I: P-S. Helsinki: The Neo-Assyrian Text Corpus Project.

PNA 3/II = Baker, Heather D. (ed.) (2011). The Prosopography of the Neo-Assyrian Empire 3/II: $\check{S}$-Z. Helsinki: The Neo-Assyrian Text Corpus Project.

SAA $10=$ Parpola, Simo (1993). Letters from Assyrian and Babylonian Scholars. Helsinki: Helsinki University Press. State Archives of Assyria 10.

TADA = Porten, Bezalel; Yardeni, Ada (1986). Textbook of Aramaic Documents from Ancient Egypt. Newly Copied, Edited and Translated into Hebrew and English. 1: Letters. Jerusalem: The Hebrew University, Department of the History of the Jewish People. Textbook of Aramaic Documents from Ancient Egypt 1.

TADB = Porten, Bezalel; Yardeni, Ada (1989). Textbook of Aramaic Documents from Ancient Egypt. Newly Copied, Edited and Translated into Hebrew and English. 2: Contracts. Jerusalem: The Hebrew University, Department of the History of the Jewish People.
Textbook of Aramaic Documents from Ancient Egypt 2.

TADC = Porten, Bezalel; Yardeni, Ada (1993). Textbook of Aramaic Documents from Ancient Egypt. Newly Copied, Edited and Translated into Hebrew and English. 3: Literature, Accounts, Lists. Jerusalem: The Hebrew University, Department of the History of the Jewish People. Textbook of Aramaic Documents from Ancient Egypt 3.

TADD = Porten, Bezalel; Yardeni, Ada (1999). Textbook of Aramaic Documents from Ancient Egypt. Newly Copied, Edited and Translated into Hebrew and English. 4: Ostraca and Assorted Inscriptions. Jerusalem: The Hebrew University, Department of the History of the Jewish People. Textbook of Aramaic Documents from Ancient Egypt 4.

$\mathrm{WH}=$ Winnett, Frederick V.; Harding, Gerald L. (1978). Inscriptions from Fifty Safaitic Cairns. Toronto: University of Toronto Press. Near and Middle East Series 9. 


\section{Bibliography}

Ababneh, Mohammad I. (2005). Neue safaitische Inschriften und deren bildliche Darstellungen. Aachen: Shaker Verlag. Semitica et Semitoa hamitica Berolinensia 6.

Abbadi, Sabri (1983). Die Personennamen der Inschriften aus Hatra. Hildesheim-Zürich-New York: Georg Olms Verlag. Texte und Studien zur Orientalistik 1.

Abousamra, Gaby (2015). "Palmyrene Inscriptions on Seven Reliefs". Semitica, 57, 217-42.

Abraham, Kathleen (2005-6). "West Semitic and Judean Brides in Cuneiform Sources from the Sixth Century BCE. New Evidence from a Marriage Contract from Āl-Yahudu". Archiv für Orientforschung, 51, 198-219.

Abraham, Kathleen; Sokoloff, Michael (2011). "Aramaic Loanwords in Akkadian. A Reassessment of the Proposals". Archiv für Orientforschung, 52, 22-76.

Aggoula, Basile (1972). "Remarques sur les inscriptions hatréennes II". Mélanges de l'Université Saint-Joseph, 47, 3-84.

Aggoula, Basile (1977). "Remarques sur les inscriptions hatréennes V". Semitica, 27, 123-43.

Aggoula, Basile (1981). "Remarques sur les inscriptions hatréennes VI". Syria, 58(3-4), 363-78.

Aggoula, Basile (1983a). "Remarques sur les inscriptions hatréennes VIII". Syria, 60(1-2), 101-5.

Aggoula, Basile (1983b). "Remarques sur les inscriptions hatréennes IX". Syria, 60(3-4), 251-7.

Aggoula, Basile (1985a). "Inscriptions et graffites araméens d'Assour". Suppl. 43, Annali dell'Università degli Studi di Napoli 'L'Orientale', 45 (2). Aggoula, Basile (1985b). "Remarques sur les inscriptions hatréennes X". Syria, 62(3-4), 281-5.

Aggoula, Basile (1986). "Remarques sur les inscriptions hatréennes XII". Syria, 63(3-4), 353-74.

Aggoula, Basile (1990). "Remarques sur les inscriptions hatreénnes XVIXIX". Syria, 67(3-4), 397-421.

Aggoula, Basile (1991). Inventaire des inscriptions hatréennes. Paris: Geuthner. Institut Français d'Archéologie du Proche-Orient, Bibliothèque Archéologique et Historique 139.

Al-Jallad, Ahmad (2015). An Outline of the Grammar of the Safaitic Inscriptions. Leiden; Boston: Brill. Studies in Semitic Languages and Linguistics 80.

Al-Jallad, Ahmad (2017). "Graeco-Arabica I: The Southern Levant". AlJallad, Ahmad (ed.), Arabic in Context. Celebrating 400 Years of Arabic at Leiden University. Leiden; Boston: Brill, 99-186. Studies in Semitic Languages and Linguistics 89. 
Alpass, Peter (2013). The Religious Life of Nabataea. Leiden; Boston: Brill. Religions in the Graeco-Roman World 175.

Andrae, Walter (1912). Hatra. Nach Aufnahmen von Mitgliedern der AssurExpedition der Deutschen Orient-Gesellschaft. II Teil. Einzelbeschreibung der Ruinen. Vol. 2 of Hatra. Nach Aufnahmen von Mitgliedern der Assur-Expedition der Deutschen Orient-Gesellschaft. Leipzig: J.C. Hinrichs'sche Buchhandlung. Wissenschaftliche Veröffentlichungen der Deutschen Orient-Gesellschaft 21.

al-As'ad, Khaled; Gawlikowski, Michal; Yon, Jean-Baptiste (2012). "Aramaic Inscriptions in the Palmyra Museum. New Acquisitions". Syria, 89, 163-84.

al-Aswad, Hikmat B. (1997-98). "Hatra: Digging of Two Private Houses South of the Big Temple" [Arabic]. Sumer, 49, 231-50.

Asmussen, Jes P. (1989). "Bar Kōnay, Theodore". Yarshater, Ehsan (ed.), Encyclopaedia Iranica III. Vol. 3 of Encyclopaedia Iranica. London; Boston: Routledge \& Kegan Paul, 737-8.

Avigad, Nahman; Sass, Benjamin (1997). Corpus of West Semitic Stamp Seals. Jerusalem: The Israel Academy of Sciences and Humanities; The Israel Exploration Society; The Institute of Archaeology, The Hebrew University of Jerusalem.

Baker, Heather D. (2002). "Approaches to Akkadian Name-Giving in FirstMillennium BC Mesopotamia". Wunsch, Cornelia (ed.), Mining the Archives. Festschrift for Christopher Walker on the Occasion of His 60th Birthday, 4 October 2002. Dresden: ISLET Verlag, 1-24. Babylonische Archive 1.

Baker, Heather D. (2004). The Archive of the Nappāhu Family. Wien: Institut für Orientalistik der Universitat Wien. Archive für Orientforschung Beiheft 30.

Benz, Frank L. (1972). Personal Names in the Phoenician and Punic Inscriptions. Rome: Biblical Institute press. Studia Pohl 8.

Bertolino, Roberto (1995). "La cronologia di Hatra. Interazione di archeologia e di epigrafia". Suppl. 83, Annali dell'Università degli Studi di Napoli 'L'Orientale', 55(2).

Bertolino, Roberto (1996a). "La paléographie hatréenne et ses rapports avec les écritures araméennes du Golfe Persique et de l'Iran". ARAM, 8, 307-13.

Bertolino, Roberto (1996b). “Une stèle inédite de Hatra”. Semitica, 46, 143-6. Bertolino, Roberto (2000). "Un'iscrizione inedita in aramaico d'impero a Hatra". Milano, Lucio; de Martino, Stefano; Fales, Frederick M.; Lanfranchi, Giovanni B. (eds.), Landscapes. Territories, Frontiers and Horizons in the Ancient Near East. Papers Presented to the XLIV Rencontre Assyriologique Internationale. Part III: Landscape in Ideology, Religion, Literature and Art. $=$ Conference Proceedings (Venezia, 7-11 July 1997). Padova: Sargon, 133-8. History of the Ancient Near East Monographs III/3. 
Bertolino, Roberto (2004). “Corpus des inscriptions sémitiques de DouraEuropos”. Suppl. 94, Annali dell'Università degli Studi di Napoli 'L'Orientale', 64.

Bertolino, Roberto (2008). Manuel d'épigraphie hatréenne. Paris: Geuthner.

Bertolino, Roberto (2013). "Scriptorial Evidence of Scratched Inscriptions from Building A in Hatra”. Peruzzetto, Dorna Metzger, Dirven 2013, 187-91.

Beyer, Klaus (1984). Die aramäischen Texte vom Toten Meer: samt den Inschriften aus Palästina, dem Testament Levis aus der Kairoer Genisa, der Fastenrolle und den alten talmudischen Zitaten. Band 1. Göttingen: Vandenhoeck \& Ruprecht.

Beyer, Klaus (1998). Die aramäischen Inschriften aus Assur, Hatra und dem übrigen Ostmesopotamien (datiert 44 v. Chr. bis 238 n. Chr.). Göttingen: Vandenhoeck \& Ruprecht.

Beyer, Klaus (2002). “Neue Inschriften aus Hatra”. Arnold, Werner; Bobzin, Hartmut (Hrsgg.), „Sprich doch mit deinen Knechten aramäisch, wir verstehen es!" 60 Beiträge zur Semitistik Festschrift für Otto Jastrow zum 60. Geburtstag. Wiesbaden: Harrassowitz Verlag, 85-90.

Beyer, Klaus (2004). Die aramäischen Texte vom Toten Meer: samt den Inschriften aus Palästina, dem Testament Levis aus der Kairoer Genisa, der Fastenrolle und den alten talmudischen Zitaten. Band 2. Göttingen: Vandenhoeck \& Ruprecht.

Beyer, Klaus (2013). “Die aramäischen Inschriften aus Assur, Hatra und dem übrigen Ostmesopotamien (datiert 44 v. Chr. bis 238 n. Chr.). Nachträge". Die Welt des Orients, 43, 25-62.

Beyer, Klaus; Livingstone, Alasdair (1987). "Die neuesten aramäischen Inschriften aus Taima”. Zeitschrift der Deutschen Morgenländischen Gesellschaft, 137(2), 285-96.

Bongenaar, Arminius C.V.M. (1997). The Neo-Babylonian Ebabbar Temple at Sippar: its Administration and its Prosopography. Leiden: Nederlands Instituut voor het Nabije Oosten. Uitgaven van het Nederlands Instituut voor het Nabije Oosten te Leiden 80.

Bowman, Raymond A. (1970). Aramaic Ritual Texts from Persepolis. Chicago: The University of Chicago Press. The University of Chicago Oriental Institute Publications 91.

Cantineau, Jean (1932). Le Nabatéen II. Choix de textes - Lexique. Paris: Libraire Ernest Leroux.

Caquot, André (1952). "Nouvelles inscriptions araméennes de Hatra”. Syria, 29(1-2), 89-118.

Caquot, André (1955a). "Nouvelles inscriptions araméennes de Hatra III”. Syria, 32(1-2), 49-58.

Caquot, André (1955b). "Nouvelles inscriptions araméennes de Hatra IV". Syria, 32(3-4), 261-72. 
Caquot, André (1963). “Nouvelles inscriptions araméennes de Hatra V”. Syria, 40(1-2), 1-16.

Caquot, André (1964). "Nouvelles inscriptions araméennes de Hatra VI". Syria, 41(3-4), 251-72.

Caquot, André (1994). Review of Aggoula 1991. Syria, 71(1-2), 251-2.

Colditz, Iris (2013). "Die parthischen Personennamen in den iranisch-manichäischen Texten”. Tokhtasev, Sergius; Luria, Paulus (Hrsgg.), Commentationes Iranicae. Vladimiro f. Aaron Livschits nonagenario donum natalicium. Petropoli: Nestor-Historia, 118-42.

Contini, Riccardo; Pagano, Paola (2015). "Notes on Foreign Words in Hao tran Aramaic". Butts, Aaron M. (ed.), Semitic Languages in Contact. Leiden; Boston: Brill, 126-57. Studies in Semitic Languages and Linguistics 82 .

Coogan, Michael D. (1976). West Semitic Personal Names in the Murasu Documents. Missoula: Scholars Press. Harvard Semitic Monographs 7.

Cussini, Eleonora (2004). "Palmira tra Mesopotamia e Arabia: uno sguardo onomastico". Fales, Frederick M.; Morandi Bonacossi, Daniele (a cura di), Mesopotamia e Arabia. Scavi Archeologici e Studi Territoriali delle Università Trivenete (1994-1998). Venezia: Istituto Veneto di Scienze, Lettere ed Arti, 255-76.

De Callataÿ, François (1996). “Abdissarès l’Adiabénien”. Iraq, 58, 135-45. Degen, Rainer (1970). "Neue aramäische Inschriften aus Hatra (Nr. 214230)". Die Welt des Orients, 5(2), 222-36.

Degen, Rainer (1974). “Die aramäischen Inschriften aus Taimā' und Umgebung”. Degen, Rainer; Müller, Walter W.; Röllig, Wolfgang (Hrsgg.), Neue Ephemeris für Semitische Epigraphik 2. Wiesbaden: Otto Harrassowitz, 79-98.

Degen, Rainer (1978). “Weitere Inschriften aus Hatra (Nr. 281-335)”. Degen, Rainer; Müller, Walter W.; Röllig, Wolfgang (Hrsgg.), Neue Ephemeris für Semitische Epigraphik 3. Wiesbaden: Otto Harrassowitz, 67-112.

De Jong, Albert (2013). "Hatra and the Parthian Commonwealth". Dirven, Lucinda (ed.), Hatra. Politics Culture and Religion between Parthia and Rome = Coinference Proceedings (University of Amsterdam, 18-20 December 2009). Wiesbaden: Franz Steiner Verlag, 143-60. Oriens et Occidens 21.

Diem, Werner (1973). "Die nabatäischen Inschriften und die Frage der Kasusflexion im Altarabischen”. Zeitschrift der Deutschen Morgenländischen Gesellschaft, 123(2), 227-37.

Diem, Werner (1981). "Untersuchungen zur frühen Geschichte der arabischen Orthographie III. Endungen und Endschreibungen". Orientalia 50(4), 332-83.

Dijkstra, Klaas (1995). Life and Loyalty: a Study in the Socio-Religious Culture of Syria and Mesopotamia in the Graeco-Roman Period Based 
on Epigraphical Evidence. Leiden; New York; Köln: Brill. Religions in the Graeco-Roman World 128.

Dirven, Lucinda (2005). " $\Sigma$ HMHION, SMY', SIGNUM. A Note on the Romanization of the Semitic Cultic Standard". Parthica, 7, 119-36.

Dirven, Lucinda (2009). "My Lord With His Dogs. Continuity and Change in the Cult of Nergal in Parthian Mesopotamia". Greisiger, Lutz; Raml melt, Claudia; Tubach, Jürgen (eds.), Edessa in hellenistisch-römischer Zeit. Religion, Kultur und Politik zwischen Ost und West $=$ Beiträge des internationalen Edessa-Symposiums (Halle an der Saale, 14.-17. Juli 2005). Würzburg: Ergon Verlag, 47-68. Beiruter Texte und Studien 116.

Dirven, Lucinda (2013a). "A Goddess with Dogs from Hatra". Peruzzetto, Dorna Metzger, Dirven 2013, 147-59.

Dirven, Lucinda (ed.) (2013b). Hatra. Politics Culture and Religion between Parthia and Rome $=$ Conference Proceedings of the conference (University of Amsterdam, 18-20 December 2009). Wiesbaden: Franz Steiner Verlag. Oriens et Occidens 21.

Dirven, Lucinda (2015). "Horned Deities of Hatra. Meaning and Origin of a Hybrid Phenomenon". Mesopotamia, 50, 243-60.

Dobbs-Allsopp, Frederick W. et al. (2005). Hebrew Inscriptions. Texts from the Biblical Period of the Monarchy with Concordance. New Haven; London: Yale University Press.

Donbaz, Veysel; Stolper, Matthew W. (1997). Istanbul Murašû Texts. Istanbul: Nederlands Historisch-Archaeologisch Instituut te Istanbul. Uitgaven van het Nederlands Instituut voor het Nabije Oosten te Leiden 79.

Doty, Laurence T. (2012). Cuneiform Documents from Hellenistic Uruk. New Haven; London: Yale University Press. Yale Oriental Series, Babylonian Texts 20.

Drijvers, Han J.W. (1978). "Mithra at Hatra? Some Remarks on the Problem of the Irano-Mesopotamian Syncretism". Duchesne-Guillemin, Jacques (ed.), Études mithraiques = Actes du $2 e$ congrès international, (Téhéran, du 1er au 8 septembre 1975). Leiden: Brill, 151-86. Acta Iranica $17=$ Actes du Congrès, 1st series, 4.

Drost-Abgarjan, Armenuhi; Kotjatko-Reeb, Jens; Tubach, Jürgen (Hrsgg.) (2008). Vom Nil an die Saale. Festschrift für Arafa Mustafa zum 65. Geburtstag am 28. Februar 2005. Halle (Saale): Martin-Luther-Universität Halle-Wittenberg. Hallesche Beiträge zur Orientwissenschaft 42.

Drower, Ethel S.; Macuch, Rudolf (1963). A Mandaic Dictionary. Oxford: Clarendon Press.

Dupont-Sommer, André (1945-46). "Un ostracon aramèèn inédit de Larn sa". Revue d'assyriologie et d'archéologie orientale, 40(3-4), 143-7.

Dušek, Jan (2007). Les manuscrits araméens du Wadi Daliyeh et la Samarie vers 450-332 av. J.-C. Leiden; Boston: Brill. Culture and History of the Ancient Near East 30. 
Edzard, Dietz O. (1998-2001). “Name, Namengebung. A. Sumerisch. B. Akkadisch". Edzard, Dietz O. (Hrsg.), Reallexikon der Assyriologie und Vorderasiatischen Archäologie 9. Berlin; New York: Walter de Gruyter \& Co., 94-116.

Eissfeldt, Otto (1963). “'Gut Glück!' in Semitischer Namengebung”. Journal of Biblical Literature, 82(2), 195-200.

Fales, Frederick M. (1986). Aramaic Epigraphs on Clay Tablets of the NeoAssyrian Period. Roma: Università degli Studi “La Sapienza”. Studi SeU mitici Nuova Serie 2 .

Fales, Frederick M. (2017). “Aramaic Compositions”. Lawson Younger Jr., Kenneth (ed.), The Context of Scripture. 4. Supplements. Leiden; Boston: Brill, 99-114.

Farès-Drappeau, Saba (2005). Dédān et Lihyān: Histoire des Arabes aux confins des pouvoirs perse et hellénistique (IVe-IIe avant l'ère chrétienne). Lyon: Maison de l'Orient et de la Méditerranée Jean Pouilloux. Travaux de la Maison de l’Orient et de la Méditerranée 42.

Foietta, Enrico; Marcato, Enrico (2018). "A Review of the Sequence of Hatra Rulers in light of the Inscription H416". Parthica, 20.

Fowler, Jeaneane D. (1988). Theophoric Personal Names in Ancient Hebrew: A Comparative Study. Sheffield: Academic Press. Journal for the Study of the Old Testament Supplement Series 49.

Gignoux, Philippe (1986). Noms propres sassanides en moyen-perse épigraphique. Wien: Verlag der Österreichischen Akademie der Wissenschaften. Iranisches Personennamenbuch Band II: Mitteliranische Personennamen, Faszikel 5.

Gignoux, Philippe (2003). Noms propres sassanides en moyen-perse épigraphique. Supplement [1986-2001]. Wien: Verlag der Österreichischen Akademie der Wissenschaften. Iranisches Personennamenbuch Band II: Mitteliranische Personennamen, Faszikel 3.

Gignoux, Philippe; Jullien, Christelle; Jullien, Florence (2009). Noms propres syriaques d'origine iranienne. Wien: Verlag der Österreichischen Akademie der Wissenschaften. Iranisches Personennamenbuch Band VII: Iranische Namen in Semitischen Nebenüberlieferungen, Faszikel 5.

Golinets, Viktor (2008). “Der Name 'Elischeba', die Zahl Sieben und semitische Onomastik. Mit dem Exkurs: Die mesopotamische Gottheit Sebettu”. Reinhold, Gotthard G.G. (Hrsg.), Die Zahl Sieben im Alten Orient. Studien zur Zahlensymbolik in der Bibel und ihrer altorientalischen Umwelt. Frankfurt am Main: Peter Lang, 105-43.

Grassi, Giulia F. (2012). Semitic Onomastics from Dura Europos. The Names in Greek Script and from Latin Epigraphs. Padova: S.A.R.G.O.N. History of the Ancient Near East Monographs 12.

Greenfield, Jonas C. (1986). Review of Abbadi 1983. Bulletin of the School of Oriental and African Studies, 49(3), 625. 
Greenfield, Jonas C. (1988). “Nergol DHŠPT’”. Sundermann, Werner; Duchesne-Guillemin, Jacques; Vahman, Fereydun (eds.), A Green Leaf. Papers in Honour of Professor J. Asmussen. Leiden: Brill, 135-43. Acta Iranica 28 = Hommages et Opera Minora, 2nd series, 12 .

Greisiger, Lutz (2008). “Šarbēl: Göttin, Priester, Märtyrer. Einige Probleme der spätantiken Religionsgeschichte Nordmesopotamiens". DrostAbgarjan, Kotjatko-Reeb, Tubach 2008, 127-47.

Gröndahl, Frauke (1967). Die Personennamen der Texte aus Ugarit. Roma: Pontificium Institutum Biblicum. Studia Pohl 1.

Gzella, Holger (2008). "Aramaic in the Parthian Period: The Arsacid Inscriptions". Gzella, Holger; Folmer, Margaretha L. (eds.), Aramaic in its Historical and Linguistic Setting. Wiesbaden: Harrassowitz Verlag, 107-30. Akademie der Wissenschaften und der Literatur Mainz, Veröffentlichungen der Orientalischen Kommission 50.

Gzella, Holger (2011). “Late Imperial Aramaic”. Weninger, Stefan (ed.), The Semitic Languages. An International Handbook. In collaboration with Geoffrey Khan; Michael P. Streck; Janet C.E. Watson. Berlin; Boston: De Gruyter Mouton, 598-609. Handbücher zur Sprach- und Kom9 munikationswissenschaft 36.

Gzella, Holger (2015a). A Cultural History of Aramaic. From the Beginnings to the Advent of Islam. Leiden; Boston: Brill. Handbuch der Orientalistik 111. Gzella, Holger (2015b). Review of Grassi 2012. Archiv für Orientforschung, 53, 457-63.

Habib, J. (1973). “Hatra's Deities” [Arabic]. Sumer, 29, 157-169.

Hackl, Johannes (2013). "Frau Weintraube, Frau Heuschrecke und Frau Gut. Untersuchungen zu den babylonischen Namen von Sklavinnen in neubabylonischer und persischer Zeit". Wiener Zeitschrift für die Kunde des Morgenlandes, 103, 121-87.

Haider, Peter W. (2008). "Tradition and Change in the Beliefs at Assur, Nineveh and Nisibis between 300 BC and AD 300". Kaizer, Ted (ed.), The Variety of Local Religious Life in the Near East in the Hellenistic and Roman Periods. Leiden; Boston: Brill, 193-207. Religions in the Graeco-Roman World 164.

Hämeen-Anttila, Jakko (2000). A Sketch of Neo-Assyrian Grammar. Helsinki: The Neo-Assyrian Text Corpus Project. State Archives of Assyria Studies 13.

Harding, Gerald L. (1952). Some Thamudic Inscriptions from the Hashemite Kingdom of Jordan. Leiden: Brill.

al-Hariri, Khalil (2013). “The tomb of 'Aqraban”. Studia Palmyreńskie 12-Fifty Years of Polish Excavations in Palmyra 1959-2009 = International Conference Proceedings (Warsaw, 6-8 December 2010). Warsaw: University of Warsaw Press; Polish Centre of Mediterranean Archaeology; University of Warsaw, 149-57. 
Harnack, Dieter (1970). "Parthische Titel, vornehmlich in den Inschriften aus Hatra". Altheim, Franz; Stiehl, Ruth (Hrsgg.), Geschichte Mittelasiens im Altertum. Berlin: Walter de Gruyter \& Co., 492-549.

Hartmann, Udo; Luther, Andreas (2002). "Münzen des hatrenischen Herrn wrwd (Worod)". Schuol, Monika; Hartmann, Udo; Luther, Andreas (Hrsgg.), Grenzüberschreitungen: Formen des Kontakts zwischen Orient und Okzident im Altertum. Stuttgart: Franz Steiner Verlag, 1618. Oriens et Occidens 3.

Hayajneh, Hani (1998). Die Personennamen in den qatabānischen Inschriften. Hildesheim; Zurich; New York: Georg Olms Verlag. Texte und Studien zur Orientalistik 10.

Healey, John F. (1993). "The Nabataean Tomb Inscriptions of Mada'in Salih". Suppl. 1, Journal of Semitic Studies.

Healey, John F. (2001). The Religion of the Nabataeans. A Conspectus. Leiden; Boston; Köln: Brill. Religions in the Graeco-Roman World 136. Healey, John F. (2009). Aramaic Inscriptions and Documents of the Roman Period. New York: Oxford University Press. Textbook of Syrian Semitic Inscriptions 4.

Hess, Johann J. (1912). "Beduinennamen aus Zentralarabien”. Sitzungsberichte der Heidelberger Akademie der Wissenschaften, 19, 3-54.

Hidalgo-Chacón Díez, María del C. (2009). Die theophoren Personennamen in den dadanischen Inschriften [PhD dissertation]. Marburg: PhilippsUniversität.

Hoftijzer, Jacob; van der Kooij, Gerrit (1976). Aramaic Texts from Deir 'Alla. Leiden: Brill. Documenta et Monumenta Orientis Antiqui 11.

Ibrahim, Jabir K. (1986). Pre-islamic settlement in Jazirah. Baghdad: Republic of Iraq Ministry of Culture \& Information, State Organization of Antiquities \& Heritage.

Israel, Felice (1992). "Note di onomastica semitica 6: l'apporto della glittica all'onomastica aramaica". Vicino Oriente 8(2), 223-68.

Jastrow, Marcus (1950). A Dictionary of the Targumim, the Talmud Babli and Yerushalmi, and the Midrashic Literature. New York: Pardes Publishing House.

al-Jubouri, Bahaa A. (2010a). "Nouvelles inscriptions de Hatra”. Mesopotamia, 25, 133-44.

al-Jubouri, Bahaa A. (2010b). "Nouvelles inscriptions araméennes du temple de Nannay à Hatra". Journal of Semitic Studies, 55(1), 37-52.

Justi, Ferdinand (1895). Iranisches Namenbuch. Marburg: N.G. Elwert'sche Verlagsbuchhandlung.

Kaizer, Ted (1997). "De Dea Syria et aliis diis deabusque. A Study of the Variety of Appearances of Gad in Aramaic Inscriptions and on Sculptures from the Near East in the First Three Centuries AD (part I)". Orientalia Lovaniensia Periodica, 28, 147-66. 
Kaizer, Ted (1998). “De Dea Syria et aliis diis deabusque. A Study of the Variety of Appearances of Gad in Aramaic Inscriptions and on Sculptures from the Near East in the First Three Centuries AD (Part II)". Orientalia Lovaniensia Periodica, 29, 33-62.

Kaizer, Ted (2006). “Capital Punishment at Hatra: Gods, Magistrates and Laws in the Roman-Parthian Period". Iraq, 68, 139-53.

Kaizer, Ted (2009). "Religion and Language at Dura Europos". Cotton, Hannah et al. (eds.), From Hellenism to Islam. Cultural and Linguistic Change in the Roman Near East. Cambridge: Cambridge University Press, 235-53.

Kaufman, Stephen A. (1974). The Akkadian Influences on Aramaic. Chicago; London: The University of Chicago Press. The Oriental Institute of the University of Chicago Assyriological Studies 19.

King, Geraldine M.H. (1990). Early North Arabian Hismaic. a Preliminary Description Based on a New Corpus of Inscriptions from the Hisma Desert of Southern Jordan and Published Material [PhD dissertation]. London: School of Oriental and African Studies.

al-Khraysheh, Fawwaz (1986). Die Personennamen in den Nabatäischen Inschriften des Corpus Inscriptionum Semiticarum [PhD dissertation]. Marburg-Lahn: Philipps-Universität.

Kornfeld, Walter (1978). Onomastica Aramaica aus Ägypten. Wien: Verlag der Österreichische Akademie der Wissenschaften.

Laflı, Ergün (2016). "Five Old Syriac Inscriptions from the Museum of Şanluurfa (Ancient Edessa)". ARAM, 28(2), 443-51.

Lemaire, André (2001). Nouvelles tablettes araméennes. Genève: Librairie Droz. École pratique des hautes études, Sciences historiques et philologiques 2, Hautes etudes orientales 34.

Lemaire, André; Lozachmeur, Hélène (1998). “Les inscriptions araméennes". Davesne, Alain; Laroche-Traunecker, Françoise (éds.), Gülnar I: Le site de Meydancikkale. Recherches entreprises sous la direction d'Emmanuel Laroche (1971-1982). Paris: Ministère des affaires étrangères; Editions recherche sur les civilisations, 307-44.

Levene, Dan; Bohak, Gideon (2012). "An Incantation Bowl with a List of Deities and Toponyms". Jewish Studies Quarterly, 19(1), 56-72.

Lewis, Naphtali; Yadin, Yigael; Greenfield, Jonas C. (1989). The Documents from the Bar Kokhba Period in the Cave of Letters. Greek Papyri, Aramaic and Nabataean Signatures and Subscriptions. Jerusalem: Israel Exploration Society, The Hebrew University of Jerusalem, The Shrine of the Book. Judean Desert Studies 2.

Lightfoot, Chris S.; Naveh, Joseph (1991). “A North Mesopotamian Aramaic Inscription on a Relief in the Tigris Gorge". ARAM, 3(2), 319-36. Lipiński, Edward (1974). "אשיחו and אשבל and Parallel Personal Names". Orientalia Lovaniensia Periodica, 5, 5-13. 
Lipiński, Edward (1975). Studies in Aramaic Inscriptions and Onomastics I. Leuven: Leuven University Press. Orientalia Lovaniensia Analecta 1. Lipiński, Edward (1982). "Le culte d'Ištar en Mésopotamie du Nord à l'époque parthe". Orientalia Lovaniensia Periodica, 13, 117-24.

Lipiński, Edward (2010). Studies in Aramaic Inscriptions and Onomastics III. Ma'lānā. Leuven; Paris; Walpole (MA): Uitgeverij Peeters en Department Oosterse Studies. Orientalia Lovaniensia Analecta 200.

Livingstone, Alasdair (2009). "Remembrance at Assur: the Case of the Dated Aramaic Memorials". Luukko, Mikko; Svärd, Saana; Mattila, Raija (eds.), Of God(s), Trees, Kings, and Scholars. Neo-Assyrian and Related Studies in Honour of Simo Parpola. Helsinki: The Finnish Oriental Society, 151-7. Studia Orientalia 106.

Löw, Immanuel (1924). Die Flora der Juden. II: Iridaceae-Papilionaceae. Vol. 2 of Die Flora der Juden. Wien; Leipzig: R. Löwit Verlag. Veröffentlichungen der Alexander Kohut Memorial Foundation 2.

Macdonald, Michael C.A. (1999). "Personal Names in the Nabataean Realm: a Review Article". Journal of Semitic Studies, 44(2), 251-89.

Macdonald, Michael C.A. (2005). "The Safaitic Inscriptions at Dura Europos". Cussini, Eleonora (ed.), A Journey to Palmyra. Collected Essays to Remember Delbert R. Hillers. Leiden; Boston: Brill, 118-29. Culture and History of the Ancient Near East 22.

Macdonald, Michael C.A. (2009). Literacy and Identity in pre-Islamic Arabia. Aldershot: Ashgate. Variorum Collected Studies 906.

MacKenzie, David N. (1971). A Concise Pahlavi Dictionary. London; New York; Toronto: Oxford University Press.

al-Manaser, Ali Y.K. (2008). Ein Korpus neuer safaitischer Inschriften aus Jordanien. Aachen: Shaker Verlag. Semitica et Semitohamitica Berolinensia 10.

Maraqten, Mohammed (1988). Die semitischen Personennamen in den alt- und reichsaramäischen Inschriften aus Vorderasien. Hildesheim; Zürich; New York: Georg Olms Verlag. Texte und Studien zur Orientalistik 5.

Maraqten, Mohammed (1996). "The Aramaic Pantheon of Taymā'”. Arabian Archaeology and Epigraphy, 7, 17-31.

Marcato, Enrico (2016). "The Onomastics of Hatra as Evidence for Cultural Interactions". ARAM, 28(2), 345-57.

Marciak, Michał (2017). Sophene, Gordyene, and Adiabene. Three Regna Minora of Northern Mesopotamia Between East and West. Leiden: Brill. Impact of Empire 26.

Marciak, Michał; Wójcikowski, Robert S. (2016). "Images of Kings of Adiabene. Numismatic and Sculptural Evidence". Iraq, 78, 79-101.

Mascitelli, Daniele (2006). L'arabo in epoca preislamica. Formazione di una lingua. Roma: «L'ERMA» di BRETSCHNEIDER. Arabia Antica 4, Philological Studies. 
McEwan, Gilbert J.P. (1981). Priest and Temple in Hellenistic Babylonia. Wiesbaden: Franz Steiner Verlag GMBH. Freiburger Altorientalische Studien 4.

Metzger, Bruce M. (1968). Historical and Literary Studies: Pagan, Jewish and Christian. Leiden: Brill. New Testament Tools and Studies 8.

Milik, Józef T. (1962). “A propos d'un atelier monetaire d'Adiabene: Natounia". Revue Numismatique, 4, 51-8.

Milik, Józef T. (1967). “Inscription araméenne en caractères grecs de Doura-Europos et une dédicace grecque de Cordoue". Syria, 44(3-4), 289-306.

Milik, Józef T. (1972). Recherches d'épigraphie proche-oriéntale I. Dédicaces faites par des dieux. (Palmyre, Hatra, Tyr) et des thiases sémitiques à l'époque romaine. Paris: Geuthner. Bibliothèque Archéologique et Historique 92.

Militarev, Alexander; Kogan, Leonid (2005). Semitic Etymological Dictionary. Vol. II. Animal Names. Münster: Ugarit Verlag. Alter Orient und Altes Testament 278/2.

Moore Cross, Frank (2006). "Personal Names in the Samaria Papyri". Bulletin of the American Schools of Oriental Research, 344, 75-90.

Moriggi, Marco (2009). Review of Bertolino 2008. Studi Epigrafici e Linguistici sul Vicino Oriente antico, 26, 108-10.

Moriggi, Marco (2010a). "Recent Studies in Hatran Aramaic Texts”. Mesopotamia, 45, 123-32.

Moriggi, Marco (2010b). “Varia Epigraphica Hatrena”. Parthica, 12, 69-79.

Moriggi, Marco (2012). "Middle Aramaic: Outlines for a Definition”. Beti tini, Lidia; La Spisa, Paolo (éds.), Au-delà de l'arabe standard. Moyenarabe et arabe mixte dans les sources médiévales, modernes et contemporaines. Firenze: Università di Firenze, Dipartimento di scienze dell'antichità, Medioevo e Rinascimento e linguistica, 279-89. Quaderni di Semitistica 28.

Moriggi, Marco (2013a). "New and Old Evidence on Hatran Aramaic". Annali dell'Università degli Studi di Napoli "L'Orientale". Sezione orienn tale, 73, 33-48.

Moriggi, Marco (2013b). “Hatra and Western Jazīrah: Some Remarks on the Epigraphic Evidence". Mengozzi, Alessandro; Tosco, Mauro (eds.) Sounds and Words through the Ages: Afroasiatic Studies from Turin. Alessandria: Edizioni dell'Orso, 315-21. The Department of Humanities (Asia, Africa and the Mediterranean) University of Turin, Italy StudiUm DOST Critical Studies 14.

Moriggi, Marco (forthcoming). “Aramaic Ostraca from Kifrin”. Lippolis, Carlo (a cura di), Kifrin: una roccaforte sull'Eufrate. Torino: Centro Ricerche Archeologiche e Scavi di Torino per il Medio Oriente e l'Asia. 
Moriggi, Marco (forthcoming). Aramaic Graffiti from Hatra. A Study based on the Archive of the Missione Archeologica Italiana. Leiden; Boston: Brill.

Moriggi, Marco; Bucci, Ilaria (2016). "Unpublished Graffiti from Hatra". Parthica, 18, 107-24.

Müller-Kessler, Christa (2016). "Edessa, Hatra, and Palmyra: A Florilegium of Inscriptions from the Fertile Crescent". ARAM, 28(2), 471-83.

Muth, Franz-Christoph (2008). "Proper Names". Veerstegh, Kees (ed.), Encyclopedia of Arabic Language and Linguistics. III. Lat-Pu. Vol. 3 of Encyclopedia of Arabic Language and Linguistics. Leiden; Boston: Brill, 717-24.

Negev, Avraham (1991). Personal Names in the Nabataean Realm. Jerusalem: The Institute of Archaeology, The Hebrew University of Jerusalem. Qedem, Monographs of the Institute of Archaeology 32.

Nielsen, John P. (2015). Personal Names in Early Neo-Babylonian Legal and Administrative Tablets, 747-626 B.C.E. Winona Lake (IN): Eisenbrauns. Nisaba 29.

Nitta, Ermenegildo (1989). "Antroponimi semitici nelle iscrizioni greche e latine della Emesene". Civiltà classica e cristiana, 10(2), 283-302.

Noth, Martin (1928). Die israelitischen Personennamen im Rahmen der gemeinsemitischen Namengebung. Stuttgart: Kohlhammer. Beiträge zur Wissenschaft vom Alten und Neuen Testament 46.

Oates, David (1955). "A Note on three Latin Inscriptions from Hatra". Sumer, 11, 39-43.

Odishu, Daniel I. (1990). The Aramaic Inscriptions of Hatra [PhD dissertation]. Cardiff: University of Wales.

Pearce, Laurie E.; Wunsch, Cornelia (2014). Document of Judean Exiles and West Semites in Babylonia in the Collection of David Sofer. Bethesda (MD): CDL Press. Cornell University Studies in Assyriology and Sumerology (CUSAS) 28.

Pennacchietti, Fabrizio A. (1987). "Considerazioni sul testo legale contenuto nell'iscrizione aramaica n. 344 di Hatra (Iraq)". Atti del Sodalizio Glottologico Milanese, 29, 109-20.

Pennacchietti, Fabrizio A. (1988a). "Le iscrizioni aramaiche di Khirbet Ğaddāla (Iraq)". Annali dell'Istituto Universitario Orientale di Napoli, 48, 139-47.

Pennacchietti, Fabrizio A. (1988b). "Tre note di epigrafia hatrena". Mesopotamia, 23, 43-64.

Pennacchietti, Fabrizio A. (1996). "Il medio aramaico orientale alla luce di testi epigrafici inediti di Hatra (Irak)". Incontri Linguistici, 19, 59-68.

Pennacchietti, Fabrizio A. (1998). "Iscrizioni aramaiche hatrene su un sostegno fittile". Mesopotamia, 33, 275-89.

Pennacchietti, Fabrizio A. (2007). "Sulle tracce del dio Aquila: La radice 'QB nell'onomastica di Hatra". Voigt, Rainer (Hrsg.), Akten des 7. Inter- 
nationalen Semitohamitistenkongresses Berlin 2004. Aachen: Shaker Verlag, 391-9. Semitica et Semitohamitica Berolinensia 5.

Peruzzetto, Alessandra; Dorna Metzger, Francesca; Dirven, Lucinda (eds.) (2013). Animals, Gods and Men from East to West. Papers on Archaeology and History in Honour of Roberta Venco Ricciardi. Oxford: Archaeopress. BAR International Series 2516.

Porten, Bezalel (2016). "Akkadian Names in Aramaic Documents from Ancient Egypt". In consultation with Ran Zadok and Laurie Pearce. Bulletin of the American Schools of Oriental Research, 375, 1-12.

Pruzsinszki, Regine (2003). Die Personennamen der texte aus Emar. BeB thesda (MD): CDL Press. Studies on the Civilization and Culture of Nuzi and the Hurrians 13.

al-Qananweh, Ekhlass Kh. (2004). Transjordanische Personennamen in der eisenzeitlichen Periode und ihre semitischen Entsprechungen $[\mathrm{PhD}$ dissertation]. Berlin: Freie Universität.

Radner, Karen (2002). Die Neuassyrischen Texte aus Tall Šēh̆ Hamad. Mit Beiträgen von Wolfgang Röllig zu den aramäischen Beischriften. Berlin: Dietrich Reimer Verlag. Berichte der Ausgrabung Tall Šēḩ Hamad / Dūr Katlimmu (BATSH) 6.

Radner, Karen (2006-8). "Salmānu". Streck, Michael P. (Hrsg.), Reallexikon der Assyriologie und Vorderasiatischen Archäologie, vol. 11. Berlin: Walter de Gruyter \& Co., 587-8.

Rawan, Schirin (2013). Neue safaitische Inschriften aus Süd-Syrien. Aachen: Shaker Verlag. Semitica et Semitohamitica Berolinensia 16.

Reade, Julian E. (1998). “Greco-Parthian Nineveh". Iraq, 68, 65-83.

Rechenmacher, Hans (2012). Althebräische Personennamen. Münster: Ugarit Verlag. Lehrbücher orientalischer Sprachen II/1.

Ricciardi Venco, Roberta; Parapetti, Roberto (2016). "Hatra, the Sanctuary of the Sun God in Christian and Medieval Times". ARAM, 28(2), 393-428. Röllig, Wolfgang (1990). "Zwei aramäische Inschriften vom Tall Šēh Hasan/Syrien". Semitica, 39, 149-54.

Röllig, Wolfgang (2000). "Aramaica Haburensia I. Eine ostaramäische Inschrift parthischer Zeit aus Tall Šēh Hamad". Marzahn, Joachim; Neumann, Hans (Hrsgg.), Assyriologica et Semitica. Festschrift für Joachim Oelsner anläßlich seines 65. Geburtstages am 18. Februar 1997. Münster: Ugarit-Verlag, 377-86. Alter Orient und Altes Testament 252. Röllig, Wolfgang (2014). Die aramäischen Texte aus Tall Šēh Hamad / Dūr Katlimmu / Magdalu. Wiesbaden: Harrassowitz Verlag. Berichte der Ausgrabung Tall Šēh Hamad / Dūr Katlimmu (BATSH) 17.

Rostovtzeff, Michael I.; Brown, Frank E.; Welles, Charles B. (eds.) (1939). The Excavations at Dura Europos. Conducted by Yale University and the French Academy of Inscriptions and Letters. Preliminary Report of the Seventh and Eighth Seasons of Work 1933-1934 and 1934-1935. New Haven: Yale University Press. 


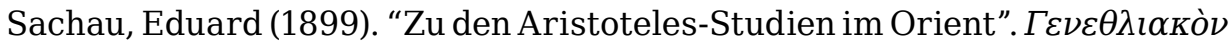
zum Buttmannstage, 5. Dezember 1899. Berlin: [s.n.], 50-64.

Safar, Fuad (1951). "Inscriptions of Hatra” [Arabic]. Sumer, 7, 170-84.

Safar, Fuad (1952). "Inscriptions of Hatra” [Arabic]. Sumer, 8, 183-95.

Safar, Fuad (1953). "Inscriptions of Hatra” [Arabic]. Sumer, 9, 240-59.

Safar, Fuad (1961). "Inscriptions of Hatra” [Arabic]. Sumer, 17, 9-35.

Safar, Fuad (1962). "Inscriptions of Hatra” [Arabic]. Sumer, 18, 21-64.

Safar, Fuad; Mustafa, Muhammad A. (1974). Hatra: The City of the Sun God [Arabic]. Baghdad: Wizārat al-I'lām, Mudiriyyat al-Ātār al-'Āmma. al-Said, Said F. (1995). Die Personennamen in den minäischen Inschriften: eine etymologische und lexikalische Studie im Bereich der semitischen Sprachen. Wiesbaden: Harrassowitz.

al-Salihi, Wathiq I. (1975). "Inscriptions of Hatra” [Arabic]. Sumer, 31, 171-88.

al-Salihi, Wathiq I. (1987). "Palmyrene Sculptures Found at Hatra”. Iraq, 49, 53-61.

al-Salihi, Wathiq I. (1996a). “Two Cult-Statues from Hatra”. Iraq, 58, 105-8.

al-Salihi, Wathiq I. (1996b). "A Stele of Baalšamin from Hatra”. Mesopotamia, 31, 189-96.

Sass, Benjamin; Marzahn, Joachim (2010). Aramaic and Figural Stamp Impressions on Bricks of the Sixth Century B.C. from Babylon. Wiesbaden: Harrassowitz Verlag. Wissenschaftliche Veröffentlichungen der Deutschen Orient-Gesellschaft 127; Ausgrabungen der Deutschen OrientGesellschaft in Babylon 10.

Schmitt, Rüdiger (1998). "Parthische Sprach- und Namenüberlieferung aus arsakidischer Zeit". Wiesehöfer, Josef (Hrsg.), Das Partherreich und seine Zeugnisse. The Arsacid Empire: Sources and Documentation = Beiträge des internationalen Colloquiums (Eutin, 27. - 30. Juni 1996). Stuttgart: Franz Steiner Verlag, 163-204. Historia 122.

Schmitt, Rüdiger (2016). Personennamen in parthischen epigraphischen Quellen. Wien: Verlag der Österreichischen Akademie der Wissenschaften. Iranisches Personennamenbuch Band II: Mitteliranische Namen, Faszikel 5.

Segal, Judah B. (1983). Aramaic Texts from North Saqqâra. With some Fragments in Phoenician. London: Egypt Exploration Society. Excavations at North Saqqâra 4.

Shaked, Shaul (2016). "A New Aramaic Inscription from the Hatra Region" [Hebrew]. Eretz Israel 32 (Naveh Memorial Volume), 191-7.

Silverman, Michael H. (1981). "Servant ('ebed) Names in Aramaic and in the Other Semitic Languages". Journal of the American Oriental Society, 101(3), 361-6.

Silverman, Michael H. (1985). Religious Values in the Jewish Proper Names at Elephantine. Kevelaer: Butzon\&Bercker; Neukirchen-Vluyn: Neue 
kirchner Verlag des Erziehungsvereins. Alter Orient und Altes Testament 217.

Sima, Alexander (1995-96). Review of Aggoula 1991. Archiv für Orientforschung, 42-43, 316-22.

Sima, Alexander (1999). Die lihyanischen Inschriften von al-'Udayb (SaudiArabien). Rahden/Westf.: Verlag Marie Leidorf GmbH. Epigraphische Forschungen auf der Arabischen Halbinsel 1.

Sima, Alexander (2000). Review of Beyer 1998. Orientalische Literaturzeitung, 95(2), 162-7.

Sokoloff, Michael (2002a). A Dictionary of Jewish Palestinian Aramaic of the Byzantine Period. 2nd ed. Ramat-Gan: Bar Ilan University PressBaltimore; London: The Johns Hopkins University Press. Dictionaries of Talmud, Midrash and Targum 2; Publications of the Comprehensive Aramaic Lexicon Project.

Sokoloff, Michael (2002b). A Dictionary of Jewish Babylonian Aramaic of the Talmudic and Geonic Periods. Ramat-Gan: Bar Ilan University PressBaltimore; London: The Johns Hopkins University Press. Dictionaries of Talmud, Midrash and Targum 3; Publications of the Comprehensive Aramaic Lexicon Project.

Sokoloff, Michael (2009). A Syriac Lexicon. A Translation from the Latin, Correction, Expansion, and Update of C. Brockelmann's Lexicon Syriacum. Winona Lake (IN): Eisenbrauns; Piscataway (NJ): Gorgias Press.

Stamm, Johann J. (1939). Die akkadische Namengebung. Leipzig: J.C. Hinrichs Verlag. Mitteilungen der Vorderasiatisch-Ägyptischen Gesellschaft 44.

Stamm, Johann J. (1965). "Hebräische Ersatznamen”. Güterbock, Hans G.; Jacobsen, Thorkild (eds.), Studies in Honor of Benno Landsberger on His Seventy-Fifth Birthday, April 21, 1965. Chicago: The University of Chicago Press, 413-24. The Oriental Institute of the University of Chicago Assyriological Studies 16.

Stark, Jürgen K. (1971). Personal Names in Palmyrene Inscriptions. Oxford: Clarendon Press.

Stolper, Matthew W. (1985). Entrepreneurs and Empire. The Murašû Archive, the Murašû Firm, and Persian Rule in Babylonia. Leiden: Nedere lands Historisch-Archaeologisch Instituut te Istanbul. Uitgaven van het Nederlands Historisch-Archaeologisch Instituut te Istanbul 54.

Streck, Michael P.; Weninger, Stefan (Hrsgg.) (2002). Altorientalische und semitische Onomastik. Münster: Ugarit Verlag. Alter Orient und Altes Testament 296.

Tavernier, Jan (2007). Iranica in the Achaemenid Period (ca. 550-330 B.C.). Lexicon of Old Iranian Proper Names and Loanwords, Attested in Non-Iranian Texts. Leuven; Paris; Dudley (MA): Peeters. Orientalia Lovaniensia Analecta 158. 
Taylor, David G.K. (2002). "Bilingualism and Diglossia in Late Antique Syria and Mesopotamia". Adams James N.; Janse, Mark; Swain, Simon (eds.), Bilingualism in Ancient Society: Language Contact and the Written Word. Oxford: Oxford University Press, 298-331.

Teixidor, Javier (1967). "The Kingdom of Adiabene and Hatra". Berytus, 17, 1-11.

Teixidor, Javier (1987). Review of Abbadi 1983. Journal of the American Oriental Society, 107(1), 137-8.

Teixidor, Javier (1991). "Remarques sur l'onomastique palmyrénienne". Studi Epigrafici e Linguistici, 8, 213-23.

al-Theeb, Solaiman A.-R. (1993). Aramaic and Nabataean Inscriptions from North-West Saudi Arabia. Riyadh: King Fahd National Library.

Tubach, Jürgen (2008). “Die Etymologie der Gottesnamen 'Aglibōl, Yarhiibōl und Malaḱbēl". Drost-Abgarjan, Kotjatko-Reeb, Tubach 2008, 411-61.

Tubach, Jürgen (2014). "Die Namen der edessenischen Könige und ihre Verbindung zur Welt der Nomaden". Tamcke, Martin; Grebenstein, Sven (Hrsgg.), Geschichte, Theologie und Kultur des syrischen Christentums. = Beiträge zum 7. Deutschen Syrologie-Symposium (Göttingen, Dezember 2011). Wiesbaden: Harrassowitz Verlag, 405-21. Göttinger Orientforschungen; Syriaca 46.

Van den Branden, Albertus (1956). Les textes thamoudéens de Philby. 2 vols. Louvain: Publications Universitaires/Institut Orientaliste. Bibliothèque du Muséon 40.

Van der Spek, Robartus J. (1998). "Cuneiform Documents on Parthian History: the Rahimesu Archive. Materials for the Study of the Standard of Living". Wiesehöfer, Josef (Hrsg.), Das Partherreich und seine Zeugnisse. The Arsacid Empire: Sources and Documentation = Beiträge des internationalen Colloquiums (Eutin, 27. - 30. Juni 1996). Stuttgart: Franz Steiner Verlag, 205-58. Historia 122.

Vattioni, Francesco (1965). "A proposito di brzqjq' di Hatra". Orientalia NS, 34(3), 338-9.

Vattioni, Francesco (1981). "Le iscrizioni di Hatra". Suppl. 28, Annali dell'Università degli Studi di Napoli 'L'Orientale', 41(3).

Vattioni, Francesco (1994). "Hatra”. Suppl. 81, Annali dell'Università degli Studi di Napoli 'L'Orientale', (54)4.

Waerzeggers, Caroline (2010). The Ezida Temple of Borsippa. Priesthood, Cult, Archives. Leiden: Nederlands Instituut voor het Nabije Oosten. Achaemenid History 15.

Weber, Dieter (2005). Review of Corpus Inscriptionum Iranicarum, Part II: Inscriptions of the Seleucid and Parthian Periods and of Eastern Iran and Central Asia, Vol. II: Parthian, Parthian Economic Documents from Nisa (Texts I Pp. 161-215) by Diakonoff, Igor M. et al. (eds.). Journal of the American Oriental Society, 125(3), 410-5. 
Wehr, Hans (1985). Arabisches Wörterbuch für die Schriftsprache der Gegenwart. 5th ed. Wiesbaden: Harrassowitz Verlag.

Weisberg, David B. (1991). The Late Babylonian Texts of the Oriental Institute Collection. Malibu: Undena Publications. Bibliotheca Mesopotamica 24.

Wild, Stefan (1982). “Arabische Eigennamen”. Fischer, Wolfdietrich (Hrsg.), Grundriss der Arabischen Philologie. I. Sprachwissenschaft. Wiesbaden: Dr. Ludwig Reichert Verlag, 154-64.

Wunsch, Cornelia (2000). Das Egibi-Archiv. I. Die Felder und Gärten. Band II. Vol. 2 of Das Egibi-Archiv. I. Die Felder und Gärten. Groningen: STYX Publications. Cuneiform Monographs $20 \mathrm{~B}$.

Yadin, Yigael et al. (2002). The Documents from the Bar Kokhba Period in the Cave of Letters. Hebrew, Aramaic and Nabataean-Aramaic Papyri. Jerusalem: Israel Exploration Society-Institute of Archaeology, Hebrew University-Shrine of the Book, Israel Museum. Judean Desert Studies 3.

Yon, Jean-Baptiste (2012). Inscriptions grecques et latines de la Syrie XVII/1. Palmyre. Beyrouth: Institut Français du Proche-Orient. Bibliothèque Archéologique et Historique 195.

Yon, Jean-Baptiste (2013a). "L'épigraphie palmyrénienne depuis PAT, 19962011". Studia Palmyreńskie 12. Fifty Years of Polish Excavations in Palmyra 1959-2009 = Proceedings International Conference (Warsaw, 6-8 December 2010). Warsaw: University of Warsaw Press; Polish Centre of Mediterranean Archaeology; University of Warsaw, 333-79.

Yon, Jean-Baptiste (2013b). "Weasels and Calves. Animals and Onomastics from Qaryatain to the Euphrates". Peruzzetto, Dorna Metzger, Dirven 2013, 99-102.

Zadok, Ran (1977). On West Semites in Babylonia during the Chaldean and Achaemenian Periods. An Onomastic Study. Jerusalem: H.J. \& Z. Wanaarta and Tel-Aviv University.

Zadok, Ran (2009). Iranische Personennamen in der neu- und spätbabylonischen Nebenüberlieferung. Wien: Verlag der Österreichischen Akademie der Wissenschaften. Iranisches Personennamenbuch Band VII; Iranische Namen in Semitischen Nebenüberlieferungen, Faszikel 1B.

Zgoll, Annette (2006). Traum und Weiterleben im antiken Mesopotamien. Traumtheorie und Traumpraxis im 3.-1. Jahrtausend v. Chr. als Horizont einer Kulturgeschichte des Träumens. Münster: Ugarit-Verlag. Alter Orient und Altes Testament 333. 